2. Zur Vatertiererzeugung werden Linien bodenständiger Rassen und synthetische Iinien nach differenzierten Zuchtzielen gezïchtet. Zuchtbasis sind industriemäßige Anlagen mit I ooo bis 6 ooo Sauen. Damit ist die Grundlage für die züchterische Verbesserung der Eignung für industriemäßige Produktionsverfahren gegeben.

3. Die bei Anwendung der künstlichen Besamung hohe Selektionsintensität utıd der Nutzungsümfang der Besamungseber führen schrittweise zur genetischen Vereinheitlichung des Tiermaterials und Verbesserung ihrer Kombinationseignung für die Hybridisation.

Dieser Proze $\beta$ wird durch die Rotationspaarung von Gruppen verwandter Eber bei der Reproduktion der Linien unterstützt.

4. Ein geschlossenes Prüf- und Selektionssystem mit Vorfahren-, Eigen-, Geschwister- und Nachkommenprïfung sowohl in Stationen als auch unter Produktionsbedingungen sichert eine umfassende Leistungsinformation. Die Selektion erfolgt in Stufen entsprechend den technologischen Bedingungen der industriemäßigen Produktion. Alle Leistungsprüfungen verlaufen daher alters- oder zeitabhängig.

5. Die künstliche Besamung und das Prüfsystem erlauben, die speziellen Leistungen im. wesentlichen über das Vatertier zu selektieren, einschließlich der Nutzung von Positionseffekten. Die Selektion der Sauen kann dadurch auf die allgemeinen Leistungen und die Fruchtbarkeit konzentriert werden.

\author{
SELEKTION WEIBLICHER ZUCHTSCHWEINE UNTER DEN BEDINGEN \\ DEK INDUSTRIMASSIGEN PRODUK'TION

\section{J. FRITZSCHE} \\ Institut t. Tierzucht, Leipzig, DDR
}

I. In der DDR bildet der schrittweise Ubergang zu industriemäßigen Produktionsmethoden in der Tierproduktion eine entscheidende Methode zur erforderlichen Produktionssteigerung im Interesse der ständigen Bedarfsdeckung in quantitativer und qualitativer Hinsicht.

2. Die Nutzung industriemäßiger Produktionsmethoden in der Schweineproduktion mit Konzentration von I 000-5 600 Sauen und $6000-24000$ Mastschweinen ist möglich und führt bei der Anwendung neuer Zucht- und Selektionsmethoden zu hohen tierischen Leitsungen.

3. Die terminlich und zyklogrammgesteuerte Produktion in diesen Anlagen bedingt eine Stufenselektion der weiblichen Zuchtschweine, die mit den wesentliche fünf Haltungsstufen ïbereinstimmt.

4. 35 bis $4^{\circ}$ p. I oo der in den Anlagen für den Zweck der Reproduktion erzeugten weiblichen Ferkel sind nach der Selektion in der Aufzuchtphase als fortpflanzungsbereite Jungsauen verfügbar.

5. Der geplanten und leistungsgerechten Reproduktion der Sauenbestände kommt in den industriemäßigen Anlagen eine hohe Bedeutung zu. Dabei liegt das Optimum bei einer Reproduktionsrate von 25 bis 35 p. IOO, verstanden als Anteil der Jungsauenwürfe zu den Würfen insgesamt.

\title{
BIOCHEMICALLY CONTROLLED TRAITS AND SELECTION
}

\author{
W. SYBESMA \\ Research Institute for Animal Husbandry "Schoonoord", Zeist, The Netherland
}

The application of new techniques and physiological and biochemical methods in animal production makes it possible to reveal underlying processes of physiological nature of production characteristics.

A lot of these processes are controlled by hormones and enzymes. Certain requirements for a possible use have been mentioned. It is recommended, that more research should be done in this area in order to make tests based on these physiological sub-systems available for improvement of production traits by breeding. 